\title{
TRACES AND SCARS: THE RECONSTRUCTION OF MADRID'S CIUDAD UNIVERSITARIA AFTER THE SPANISH CIVIL WAR
}

\author{
JARA MUÑOZ HERNÁNDEZ \& JOSÉ LUIS GONZÁLEZ CASAS \\ Universidad Politécnica de Madrid, Spain
}

\begin{abstract}
Madrid's Ciudad Universitaria is a clear example of the different political era that existed in Spain during the 20th century. The project for the campus was first designed during the 1920s under the reign of Alfonso XIII, then developed throughout Spain's Second Republic, severely damaged during the Civil War, and finally rebuilt during Franco's dictatorship, continuing its expansion until the present. Today, it is also one of the most interesting examples of Spanish architectural heritage, dating from the 20th century. After the partial destruction of the campus during the war, the idea of its reconstruction was imposed over other theses that defended the conservation of the ruins as symbolic and evocative elements. We can still see this today in one of the great models of that time that has been preserved. During the process of restoration of the university complex, the new regime aimed to rebuild Ciudad Universitaria, given its enormous symbolic significance. Parts of the buildings were reconstructed according to the original project, while others were modified and some of them disappeared. The purpose of this study is to analyze the different ways of reconstruction that were carried out on campus from a self-made inventory of the solution implemented on each building. This will allow us to conclude that, to a large extent, the decision taken in the reconstruction was very much related to the position that each building occupied with regard to the war front, and thus the consequent degree of destruction to which it was exposed. The traces of the destruction and the subsequent reconstruction have remained visible over time in most faculties and technical schools. A close observation, with the aid of graphic tools such as drawings or photography, can help us understand better the footprints and traces that are still around us today but which become invisible to the eye since they are not adequately understood.

Keywords: heritage, 20th century, Madrid, university, civil war, reconstruction, drawing, photography.
\end{abstract}

\section{INTRODUCTION}

Disasters - of whichever nature - that strongly damage cultural heritage, always mark a turning point in terms of how and when we must intervene to retrieve that heritage which is at risk. The contribution we intend to make is related to the outbreak of such a terrible war as was the Spanish Civil war. Moreover, our analysis focusses on the front that was established in Madrid's Ciudad Universitaria (CU hereafter) from late 1936 until the end of the war. For three years, a newly-built campus - where both institutions and citizens had set their hopes and efforts - was progressively destroyed as a result of human barbarity.

Apart from this, war-related catastrophes always come accompanied by an added damage regarding political and social instability [1]. In this particular case, after the end of the conflict, the power was left in the hands of a regime which, on the one hand, was completely against the government which had promoted the construction of the campus, and on the other hand, was anxious to impose their imaginary on the population. All this, added to scarce policies relating to the protection of heritage, gave rise to an intense debate on the final destination of the Madrilenian campus. 


\section{THE GRAPHIC MEANS FOR THE RESEARCH}

In order to carry out this research, we have followed a methodology based on the use of two graphic instruments - drawing and photography - which help us to analyse and organize our study subject.

On the one hand, we can understand drawing from different approaches. For a start, it is an essential background source for the work we carry out. Secondly, it is also a scientific tool with which to travel to the past, in what we understand as a process of graphic reconstitution [2], and finally, it is the means with which to illustrate our results.

On the other hand, we have used photography to compare the aspect of the campus' buildings before and after the reconstruction. Thus, parting from a selection of pictures taken before the war, we locate the specific point of view of the photographer, to take a present picture as close as possible to the original one. This is not always possible, coming into play the assistance of the drawing, allowing us to overcome the physical limits imposed by reality.

The process has been as follows. First of all, parting from an urban planimetry drawing of CU in 1936 - right before the war [3] - we have superimposed the trenches, extracted from the plan that was drawn towards the end of the war (kept in AGUCM, 111/12-1.2) - to analyse from this overlapping of documents, the position of the buildings with regard to the Frontlines, and how this could be related to the level of damage the buildings suffered in the first place, and the type of reconstruction that was carried out in the second.

Afterwards, a time comparison has been made for each building existing in the campus before the war, using drawing or photography - as explained above - depending on the case (Fig. 1). We have detected different ways of reconstruction according to which the buildings have been classified. Due to the limited length of this text, we offer here only some examples of each case. However, a summary table with every building is included at the end.

Finally, following our research, we have produced a photographic catalogue of the war's traces still visible in the campus. It seemed relevant to finish this paper with a synthesis of it.
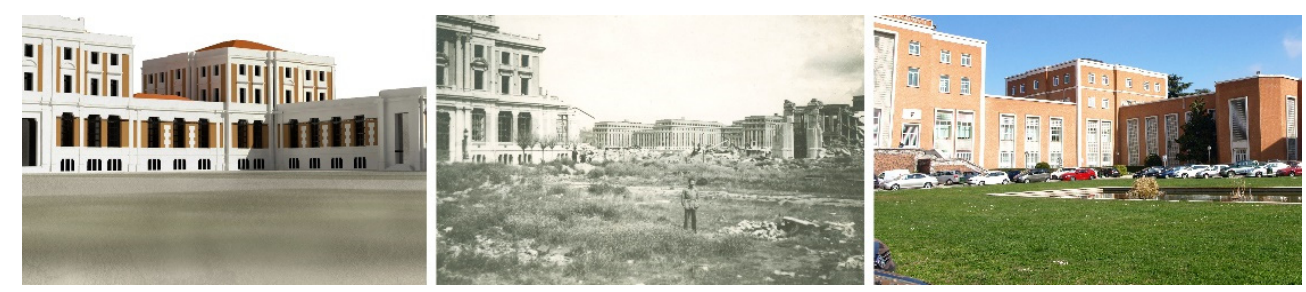

Figure 1: School of Agriculture Engineering in 1930, 1939, and 2015. (Source: Drawing: J. Muñoz. Old photography: Escuela Técnica Superior de Ingenieros Agrónomos. Current photography: J. L. González.)

\section{AN INTERRUPTED CONSTRUCTION (1927-1936)}

The CU is located on the north-west area of Madrid, on the former lands of La Moncloa Royal State [4], disentailed in 1868, after La Gloriosa revolution. The Government gave the land to the Ministry of Public Works and Transport with the aim of relocating there the Main School of Agriculture, founded in Aranjuez in 1855, and which occupied buildings which were disseminated in the area of La Moncloa.

From the last decade of the 19th century on, several institutions started to set up their headquarters in La Moncloa. They mostly had a charitable and health-related function, some 
were dedicated to leisure. Moreover, at that time, the School of Agriculture had broadened its facilities and had begun the construction of a new building to hold classrooms in it [5].

In 1920, three new transfers of land took place: one to the French State in order to build the Casa de Velázquez, another to an orphan school, and lastly, one to the Faculty of Medicine and the Clínico Hospital. Even though the last two had to wait until the design of the CU, actually, they were the seeds of the future development of the entire campus [3].

\subsection{The project and the construction of the campus}

Madrid in that time only had one university, the so-called Universidad Central, where the different faculties where disseminated around the centre of the city occupying old buildings. The need for a change in the headquarters of the university led to the creation of the Building Board Committee in May 1927. It was led by the architect Modesto López Otero, who remained in the post during both the Republic and Franco's dictatorship [6].

At the end of 1928 there was already a first draft for the design of the complex. The basic scheme of the suggested proposal can be summarized in the insertion - nowadays the exit to the city towards the north - of a main axis, named today the Avenida Complutense, around which the rest of the project for the campus was structured. The design has a vast influence from northern-American universities, since prior to this, the Committee had travelled to North America in order to find inspiration from the universities located there.

The works started at the end of Alfonso XIII reign, and were entirely carried out during the Second Republic. The irregular topography of La Moncloa was strongly altered to be able to create the platforms on top of which the new buildings would be erected. Distinguished architects of the time worked on the design and the development of the campus, such as: Aguirre, Lacasa, Sánchez Arcas, all of which under the leadership López Otero. Regarding the infrastructures, outstands the figure of the engineer Eduardo Torroja.

The construction of the campus continued until 1936. By then, part of the complex had already been completed. Both bare brick stone and cut-out openings in the walls of the façades conveyed an image of a modern architecture, characterised by straight, clean lines. In short, the aspect of the campus from north to south was the following: the building of Philosophy and Letters, inaugurated in 1933, was being used entirely, the buildings of Physical and Chemical Sciences were partially erected, the medical complex which included the Clínico Hospital was almost finished [5], and the School of Agriculture was trying to complete - with no success - its building at the same time that classes were being imparted there. At the other side of La Coruña highway, the School of Architecture was finished, the Del Amo Student's Hall was in use, and another set of student halls were in construction.

\section{THE CIUDAD UNIVERSITARIA AT WAR}

On 18 July 1936 the Spanish Civil War breaks out after the military coup d'état which had started in the north of Africa. As the military uprising in the capital was suffocated, various sections of the insurgent band tried to reach Madrid crossing the northern mountain range but were stopped by the militiamen and troops which were loyal to the Republic [7], [8]. After this unsuccessful attempt, the insurgents finally reached the capital at the beginning of November 1936. Even though the forces that protected the city had no actual training, they were able to block the rapid advancement of the troops in the outskirts of the city and managed to temporarily stabilize the front. Not long after, the volunteers belonging to the International Brigades joined in to defend Madrid. The XI International Brigade participated in the $\mathrm{CU}$ front, setting its main headquarters in the Faculty of Philosophy and Letters. 
On 15 November, the rebel troops begun the offence and managed to cross the Manzanares River, penetrating the CU till they established themselves in the School of Architecture. From this position, they advanced towards the interior of the campus during the following days, reaching the School of Agriculture Engineering, the Parque del Oeste and the Clínico Hospital. In the end, Franco decided to abandon the direct attack on the capital.

Thus, the penetration of the troops in CU meant the creation of a small rebel area within republican positions, which left it weakly communicated with the rear-guard via a series of walkways which had been created crossing the Manzanares River [9].

The positions remained basically stable during the rest of the war. In the planimetry (Fig. 2) one can observe with great precision the Francoist regime's front - that set its headquarters in the School of Architecture - from which they connected with their positions in the School of Agricultural Engineering, La Moncloa Palace, Casa de Velázquez, the edge

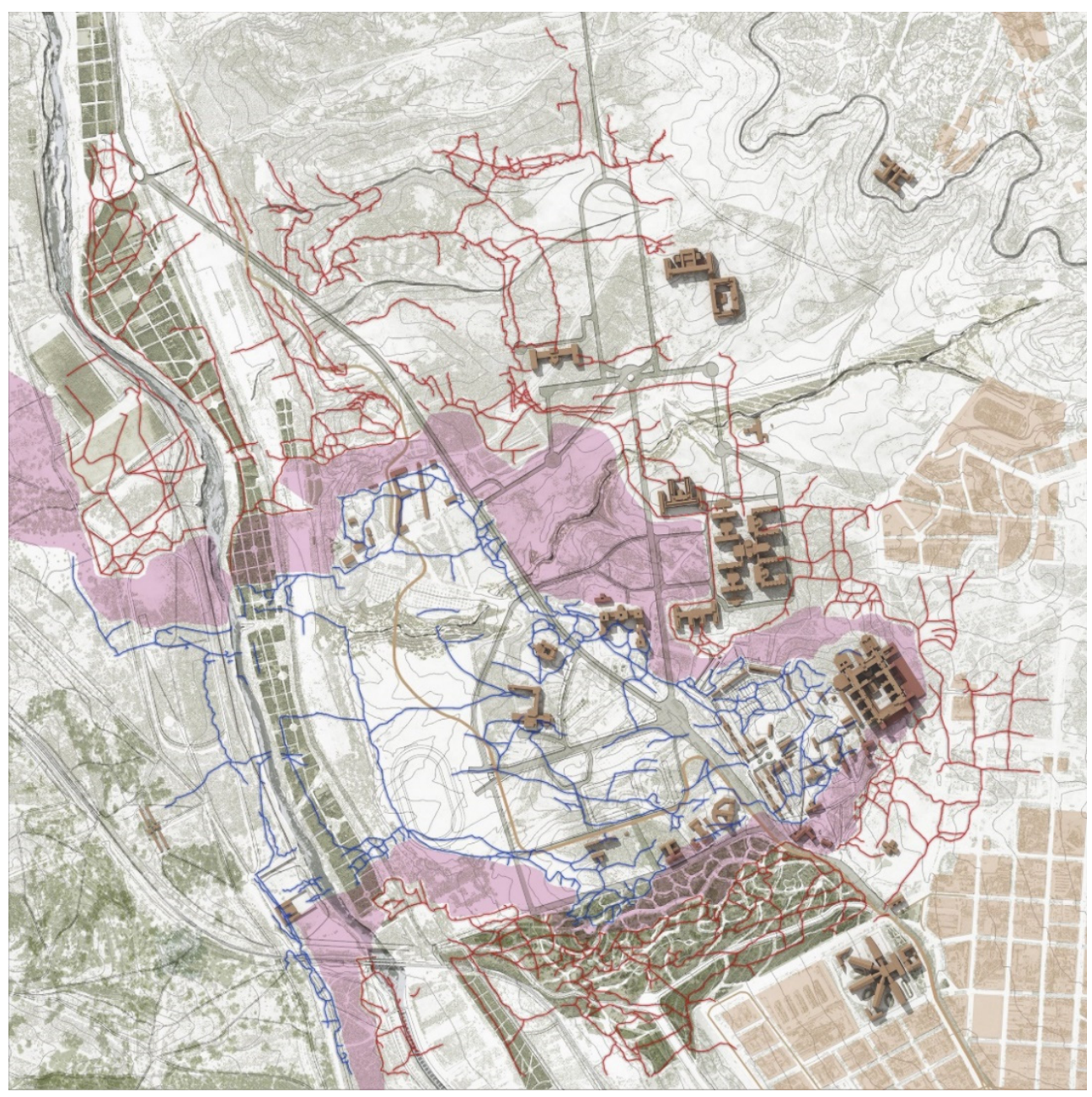

Figure 2: Location of the trenches within CU. In red are the trenches corresponding to the Republican army and in blue are those corresponding to the rebel army. In mauve, no-man's land. (Source: Drawing by the authors and L. Mauleón.) 
of the Parque del Oeste and the Clínico Hospital. The rest of the campus and the access to the urban centre remained under the Republican's control. Thus, the Republican frontline consisted of the Faculties of Philosophy and Letters, Pharmacy, Medicine and Odontology, a vast area of the Parque del Oeste and the blocks next to the Clínico Hospital. In many areas, the distance between the contenders was just a question of a few metres, as it would be the case of the School of Agriculture and the Faculty of Odontology, being this the reason behind the façades of these buildings - located in front of one another - ending completely destroyed.

In the battles which took place in CU, all sorts of weapons were used: from light weapons to mines or artillery. Proof of this, are the traces that still today remain in some of the buildings [10], as we will detail later on. Apart from aerial bombardments and the use of heavy artillery, one of the methods of attack which wreaked havoc was the battle involving mines and countermines. Once the positions were stabilized, the Republican defenders started to place mines in the positions of the attackers. At the end of the war, both sides used this strategy, which left as a result, the partial destruction of buildings such as the School of Agricultural Engineers or the Clínico Hospital. The consequence of all this was that the land of La Moncloa turned into a desolate landscape with trenches, strongpoints and numerous completely destroyed buildings. Finally, in 28 March 1939, after the Republicans surrendered, the rebel troops took over the buildings belonging to the faculties of Odontology, Medicine and Pharmacy, entering Madrid the day after that.

\section{THE RECONSTRUCTION OF THE CAMPUS}

The end of the war and the establishment of Franco's regime arose the issue of the need to make a decision with regard to the fate of the CU. According to Rodríguez-López and Muñoz Hernández [5], it is estimated that the level of destruction affected approximately $40 \%$ of the total built campus, a percentage which increases when the rest of the buildings of the area not only those strictly belonging to the campus - are also included in the estimation. Obviously, this destruction was uneven from one building to the next, depending on how exposed they had been regarding their position in the war front. In view of this scenario, the question that arose was the one concerning what to do next: to maintain the ruin as a vivid memory of the victory which had taken place there, or, on the contrary, to proceed to reconstruct the buildings.

\subsection{Ruins or reconstruction?}

At first, ruins prevailed as a testimony of the Francoist victory and the idea of their conservation stood strong, following the example of Belchite. Some authors [5], [11] use the term "martirologio" to define this practice according to which territories that have been devastated and are in ruins should be maintained as monuments for History, as a sort of evocative and "eternal memory" of the destructive power of the enemy. In a document preserved in the AGUCM (D.1770,9) they are explicit in this intention, it is said that "it is a national desire to preserve the current state (totally or partially) - and even to enhance it - of the scenery of great heroism of our glorious army. This is perfectly compatible with the draft of the road network and general layout of the land-use planning for the Ciudad Universitaria".

However, the considerable maintenance costs that preserving the ruins would have meant, made this a rather non-operational measure [12]. We cannot forget about the extreme situation regarding poverty which the population suffered during the first years of the post-war period. On the other hand, it is evident that the propaganda-driven speeches were behind the entire idea. Due to all this, this option was finally rejected, and they advocated for reconstruction. Nevertheless, this did not stop the ruins from being part of the landscape 
throughout the whole process of reconstruction of the campus: films were made, speeches were given, the area was shown proudly to foreign authorities aligned with the regime...

To be able to start the process of reconstruction three severe problems were to be faced, issues which characterized the post-war situation [1]. The main problem was the economic one. To solve this issue the strategy which was followed was the one prior to the war, using among other economic resources the income from the lottery which also helped to disseminate the image of the project for the university throughout the country. The second project was of a more technical nature. The lack of materials was worsened during the Second World War, this is the reason why materials which had been retrieved were reused or substituted by others of inferior quality - the façade of the Faculty of Pharmacy with its brick patches is a clear example of this. Finally, there was also an issue concerning changes in concept, which were solved with slight modifications of the projects, in most cases relating to the exterior image of the buildings. It is precisely in giving solution to this last problem, where the entire propaganda-load of the regime was placed on. Instead of leaving exposed the apparent wreckage that the republican troops had caused, the regime decided to make the project of CU theirs, introducing all their ideology and symbolism.

\subsubsection{Models as a testimony}

However, just to mention a last aspect regarding this debate, we may have a proof of that will to maintain that state of ruin in one of the two models that were carried out after the war to show the state in which the CU ended. The detailed materialization of this object $5.30 \times 4.05$ $\mathrm{m}$ big, was part of an evident propaganda manoeuvre since one could confront this one to the model of the reconstructed campus. Nevertheless, it could also well be an underlying intention of leaving, at least, a permanent reminder of those ruins at a smaller scale.

The other large model was built in 1943 for the inauguration event. This piece made out of plaster $5.4 \times 5.1 \mathrm{~m}$ big, is an example of the symbolic value that the Francoist regime gave to the reconstruction of the campus. Even though at first it could seem to have been built after the other one, last evidence show that they have been carried out basically at the same time. This second model aimed to show how the new reconstructed CU would be. This way, whilst the first model shows an actual state of the campus at a certain moment, the second shows an ideal of what they wanted it to be more than what actually was finally built.

Today, these two models (Fig. 3) can be seen in the hall of the Faculty of Medicine within the campus of the Universidad Complutense in Madrid (UCM).
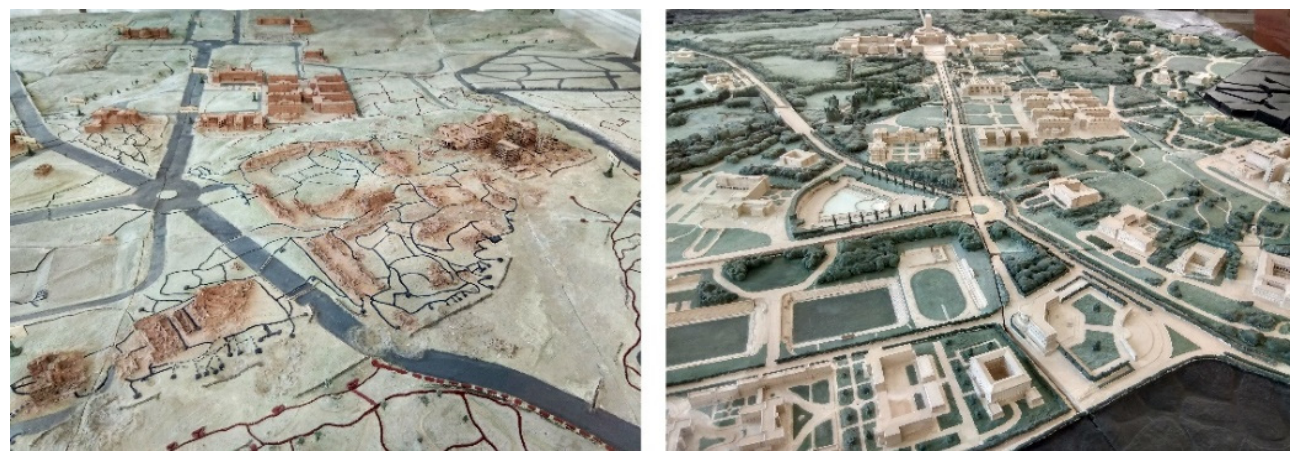

Figure 3: Left, CU's model at the end of the war, 1943. (Source: Army Museum. Ministry of Defence.) Right, CU's model with its ideal reconstruction plans, 1943. (Source: Universidad Complutense de Madrid.) 


\subsection{Ways of carrying out the reconstruction}

With the existing buildings before the war a series of different decisions were made when the moment of the reconstruction was reached. This enables us to divide them into various groups depending on the different decisions that were made regarding them. On the one hand, we have those which were rebuilt and whose footprint has been totally lost. These are the cases of the Santa Cristina Asylum or the Instituto Rubio, among others. During the summers of 2017 and 2018, a series of excavations were carried out coordinated by the archaeologist A. Pérez Ruibal where remains of the buildings of the Santa Cristina Asylum were found.

On the other hand, for all those buildings which were reconstructed, there was no uniformity in the policies to take into account, nor were they carried out immediately. The re-inaugurations started taking place in 1941 and continued well into the 1950s. The different approaches towards reconstruction that were developed, allow us to create three subgroups: new constructions, literal reconstructions and renovation of the exterior image or "changes in the skin" of the building. At the end of this section there is a detailed table which explains the sort of reconstruction which was carried out in each particular building.

\subsubsection{New constructions}

Within this group we include those buildings in which, having been partially or totally destroyed, there was no intention to reconstruct the building, although on top of them, new ones were erected, with a different sort of architecture and sometimes another use. Some authors name this "neo-reconstruction" [5], [11]. It could be considered an intermediate step between the total loss that we explained above and the reconstruction of the building.

The best example of this is the Institute of Hygiene, on top of which the José Antonio Student's Hall was erected, the rectorate at present (Fig. 4). It does not preserve the architectural style nor the use of its predecessor, but it is however located on top of the old building, probably making use of part of its foundations. That is why, after examining - in a very detailed way - the floor plan, we find that this plan holds great similarities with the back volume of the Institute of Hygiene with its "open arms", something which we would have never thought about if we had only looked and compared the photographs of the buildings. The Del Amo Student's Hall is another building which would disappear during the war since it was located really close to the front line. In the post-war period, a new student's hall would be built on that same plot. This building would have very scarce similarities - stylistic or formal - with the preceding one. One last case which is definitely worth mentioning, is La Moncloa Palace, on top of which a completely new building was erected, the palace we all know today and where the Spanish Government Headquarters is located.

\subsubsection{Literal reconstruction}

It is a type of reconstruction which, to a large extent, follows the projects which were planned to be carried out before the breakout of the war. A solution we could consider as the most pragmatic one since it took into consideration the combination of both the economic situation of the time and the lack of means and materials which made this, the most rapid and cheap way of reconstructing. A case study for this subgroup are the faculties of the medical group.

These buildings were basically finished before the war. The medical campus was placed at the very front line during the war, reason why it suffered important damages which especially affected the Faculty of Odontology because of its forefront position. The other two faculties also suffered damages in their southern and eastern façades. 

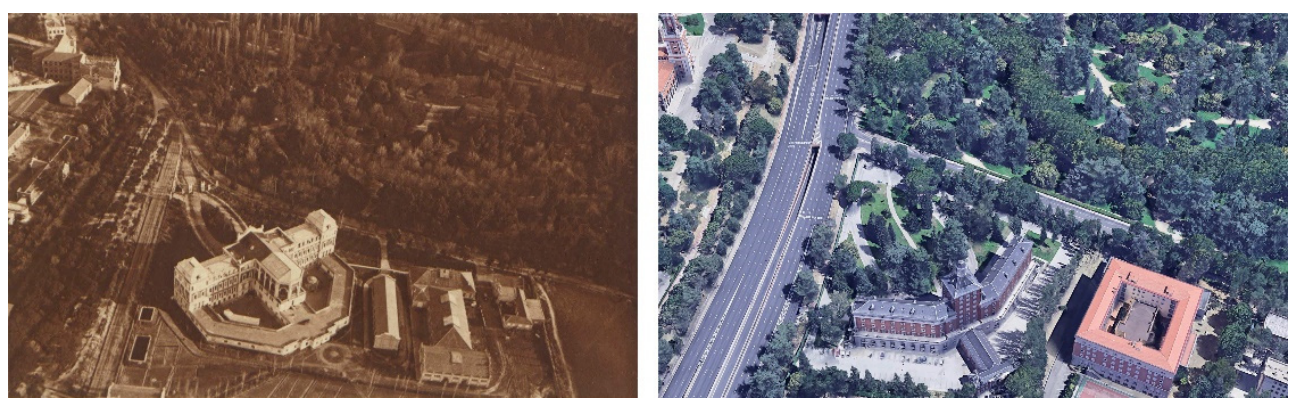

Figure 4: To the left, an aerial view of the Institute of Hygiene, 1936. (Source: Nuevo Mundo. Biblioteca Nacional de España.) To the right, a current aerial view. (Source: Google Earth.)

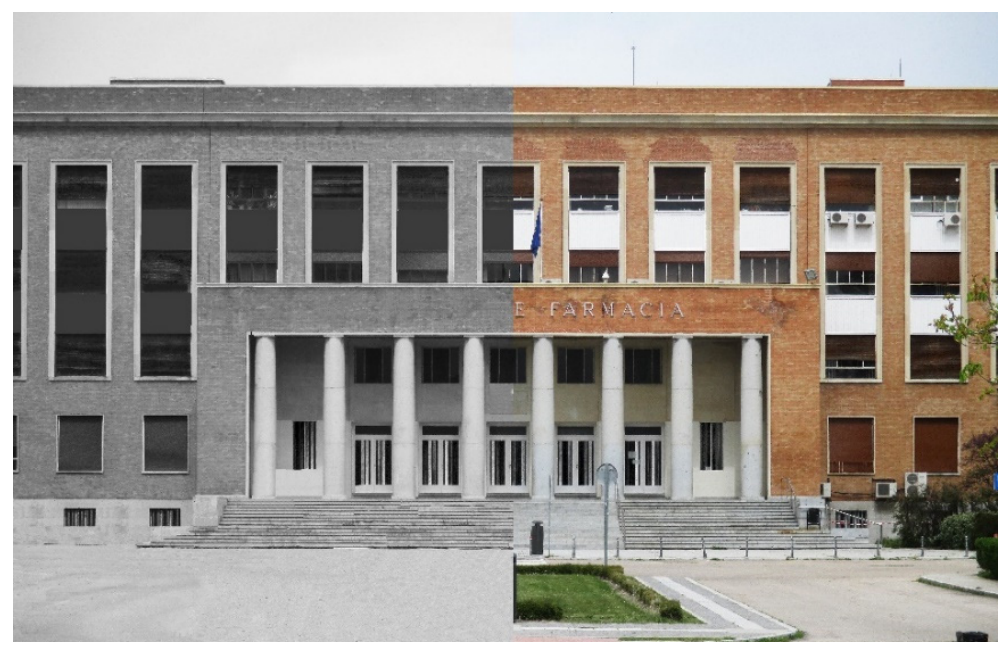

Figure 5: Façade of the Faculty of Pharmacy in 1936 and 2018. (Source: Photographs by the authors.)

As a consequence of the repairs of the damaged areas, one of the main changes that can be observed in the façades is the use of a different sort of brick than that used in the initial project - with a different quality and a different tone - which generates a clear contrast at a glance, slightly altering the unity of the façade. In terms of use or interior distributions, there are no dramatic differences between the projects. Since a large part of the building was constructed prior to 1936, it was kept intact. Years later, the decision was made to paint white the metal elements located between the windows, breaking that sensation of verticality which those dark areas - joined with the glass openings - gave the façade and which contrasted with the strong horizontality of the complex, as can be seen in the edited picture (Fig. 5).

\subsubsection{Renovation of the exterior image or "change of skin"}

Thirdly, we can talk about those buildings which were reconstructed where only its function was maintained. Its image changed substantially because of the state of destruction in which 
they had been left or because the style the building originally had did not fit in with the new guidelines set by the regime. Examples worth mentioning of this are the School of Architecture, whose brick façade was so severely damaged that the building had to be lined with Novelda sandstone plaques, and the School of Agricultural Engineering, whose original façade is covered by another of a style which the Francoist regime understood should be the style of the campus. These interventions of what we could call "change of skin" can be misleading when wanting to give exact dates and when wanting to understand the buildings. We will carry on taking the School of Agricultural Engineering as a case study.

When the war was over, the original building of the School remained almost entirely in its central volume and western wing while the eastern wing had completely disappeared. When the faculty was reconstructed, the decision was to erect the original volume, but changing its façades, a decision however which was not apparently that clear from the beginning. This can be seen in the reconstruction model dating 1943, where the School of Agricultural Engineering is complete and both side wings are symmetric with their original façades. Also, the first repairs to be able to use the building again followed the original design (plans conserved in the Administration's General Archive, 31-05500 and 31-05513).

Finally, the choice was to reconstruct the same project but changing its skin. Thus, the eastern wing was erected completely, the destroyed part of the central body of the building was reconstructed and the western wing was finished. The interventions carried out concerning the rest of the building included eliminating the orders of the columns of the façade, and also covering the façade with a new skin made out of brick. The size of the openings was also modified, and any type of ornamentation was eliminated (Fig. 6). Nevertheless, it is important to notice that the current building is not the same - if we take a look at the floor plan - than the original one as it is thought to be. Both side wings are shorter than they originally where. It is likely that as the La Coruna highway got wider, the direct consequence was that the building had to become smaller. However, it is also true that it could also have well been just a question of budget.

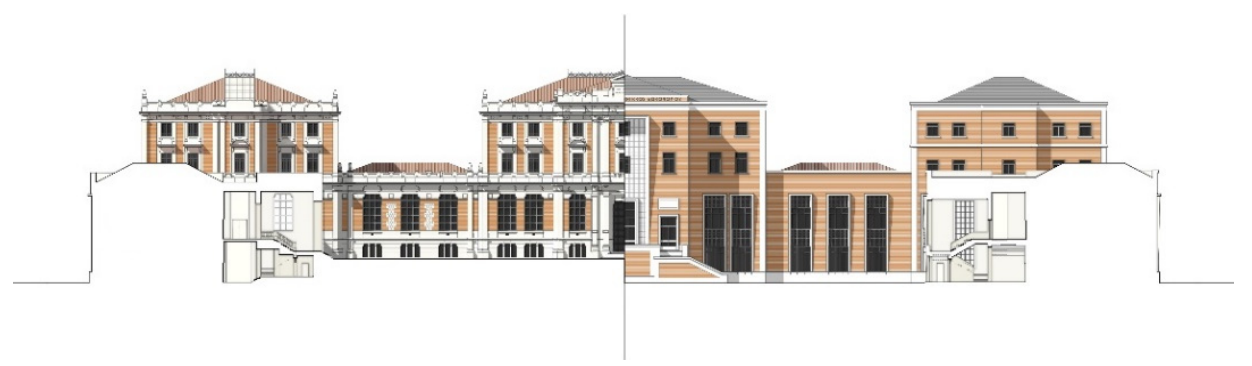

Figure 6: Façade of the School of Agricultural Engineering in 1936 and 2019. (Source: Drawing by the authors and A. Bonet.)

The other great modification that the School of Agricultural Engineering experimented regarding its prior state before the war is related to the topography of its surroundings. Currently, the building is placed on top of a continuous, flat platform. However, before the war, there was a great difference between the level at which the main façade of the building was located - at a higher level - and where the back façade of the building was, approximately $3 \mathrm{~m}$ below. This way, whilst the front of the building was only one level high (the towers were three levels high), the back façade had one extra level to it. This unevenness was solved by means of staircases placed adjacent to one of the side façades. Thus, the 
building, on the one hand, adapted more subtly to the irregular land of La Moncloa and on the other hand, it presented a more pleasant and welcoming façade towards Madrid with its smaller scale. The variations in the topography during the post-war, are the origin to some situations which can cause confusion to the visitor if they do not know the history behind the building. For example, the large staircase at the front façade - scarcely related to the rest of the building - or the fact that one does not access the main floor from street level.

\subsubsection{The ideological reconstruction}

Lastly, it is also important to talk about a type of reconstruction which is less architectural and more symbolic, but which drastically changed the appearance of the campus. The idea of reconstructing the $\mathrm{CU}$ was supported by the possibilities this space offered the regime in terms of reinforcing its image. The layout following a clear axis enabled to show the power of the rector. It also counted with the representation of the two ideological pillars of the regime: the Church and the Phalange. For that purpose, first they thought about creating a great Rectorate, parting from the first drafts carried out in 1928, to which Fascist symbols would then be added to give a new meaning to the space. However, this never actually happened, but what was constructed in the access to the campus, was the José Antonio Student's Hall, one of the best examples of Phalange architecture. They also installed chapels in every faculty and constructed the Santo Tomás de Aquino Church which would afterwards become the current American Museum. Added to these three buildings there would be another element - one with the aim to bring back the memory of the battle and the Francoist triumph than anything else. This was the Victory Arch. The vast collection of plans regarding this construction (AGUCM, 111/12-4), give us an idea of the doubts which arose at the time - and the different variations suggested - concerning this project.

Table 1: Reconstruction of the buildings of Ciudad Universitaria.

\begin{tabular}{l|c|c|c|c}
\hline Building & $\begin{array}{c}\text { State it was in } \\
\text { in } 1936\end{array}$ & $\begin{array}{c}\text { State it was in } \\
\text { in } 1939\end{array}$ & $\begin{array}{c}\text { Position within } \\
\text { the frontline }\end{array}$ & $\begin{array}{c}\text { Type of } \\
\text { reconstruction }\end{array}$ \\
\hline F. of Philosophy & Finished. In use & Semi-destroyed & Republican front & Literal \\
\hline F. Of Physics & In construction & Damaged & Republican rear & Literal \\
\hline F. Of Chemistry & In construction & Damaged & Republican rear & Literal \\
\hline F. Of Medicine & In construction & Damaged & Republican front & Literal \\
\hline F. Of Pharmacy & In construction & Damaged & Republican front & Literal \\
\hline F. Of Odontology & In construction & Semi-destroyed & Republican front & Literal \\
\hline Sch. of Agriculture & In construction & Semi-destroyed & Francoist front & Change of skin \\
\hline La Moncloa Palace & In use & Destroyed & Francoist front & New construction \\
\hline Central Farm & In use & Destroyed & Francoist front & Disappears \\
\hline Casa de Velázquez & In use & Semi-destroyed & Francoist front & Literal \\
\hline Sch. of Architecture & Finished & Semi-destroyed & Francoist front & Change of skin \\
\hline S. Cristina Asylum & In use & Destroyed & Francoist front & Disappears \\
\hline Clínico Hospital & In construction & Semi-destroyed & Francoist front & Literal \\
\hline Rubio Institute & In use & Destroyed & Francoist front & Disappears \\
\hline Cancer Institute & In use & Destroyed & Francoist front & Disappears \\
\hline Inst. of Hygiene & In use & Destroyed & Francoist front & New construction \\
\hline Del Amo Student's Hall & Finished. In use & Destroyed & Francoist front & New construction \\
\hline Thermal power station & Finished & Damaged & Republican rear & Literal \\
\hline Building Committee Hall & Finished. In use & Damaged & Republican front & Literal \\
\hline Student's Hall & In construction & Semi-destroyed & Francoist front & Literal \\
\hline
\end{tabular}




\section{WAR TRACES STILL PRESENT IN THE CIUDAD UNIVERSITARIA}

Everyday thousands of people go past CU clueless of the battle that for almost three years devastated the place. As a closing for this text we would like to point out that traces of the war can still be found all around the campus [10], either signs of war constructions or marks of destruction on previous buildings.

On the one hand, as a remain of constructed elements, we find the striking three bunkers located in the Parque del Oeste. They were carried out by the rebel troops during the last year of the war to consolidate the Frontline. Their quite good condition allows us to see the inscriptions done on them by the soldiers (Fig. 7). Although less visible, other constructed elements are the remains of the old trenches. In certain areas, what seems to be the natural topography of the place is actually the consequence of the digging of trenches. In the last years, some of them have been excavated, revealing abundant war material [8].
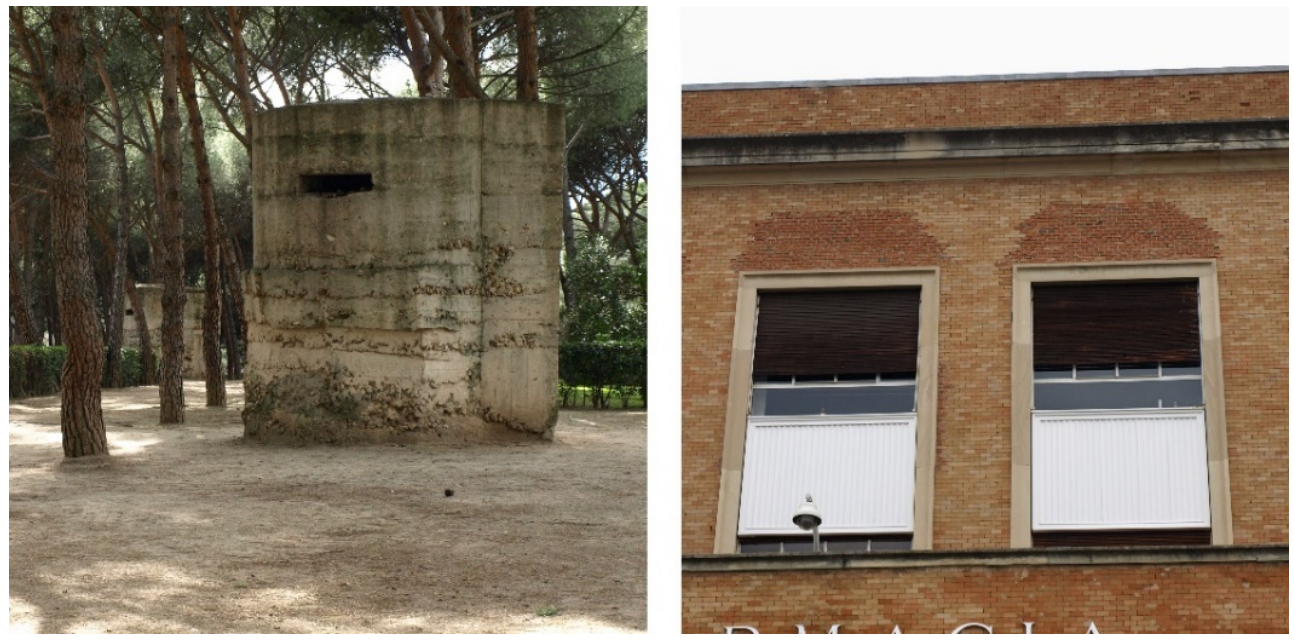

Figure 7: Bunkers in Parque del Oeste. Façade of the Faculty of Pharmacy. (Source: photographs by the authors.)

On the other hand, there are still many destruction signs in the damages caused by the impact of projectiles against various buildings and constructions. The ones which are most evident are those found in the granite plinths of the faculties of Philosophy, Medicine, Pharmacy and Odontology. The diameter and depth of the marks are a clear proof of the great variety of weapons used during the war. Also some of the reparations on the buildings do give us some clues. For example, the bricks with a more intense colour of the Faculty of Pharmacy are the evidence of the impacts which do not prevail (Fig. 7). Finally, the Faculty of Medicine is one of the few buildings where one can still see today impacts directly on the brick of the cornices. It is also very revealing that the western orientation is considerably more damaged than the rest of them, since it makes it clear that the enemy fire came from the School of Architecture.

\section{CONCLUSIONS}

In view of the results obtained from this research, the following conclusions can be drawn.

First of all, during the reconstruction of the CU there were no clear and uniform guidelines regarding the architectural aspect, although there were in the ideological one. This 
reconstruction was not an immediate decision, but maintaining the ruin was valued and in fact it has been kept in a very detailed physical model.

Secondly, the way each building was reconstructed, was closely linked to the position they occupied in relation to the Frontline. According to that position, we distinguish three cases - apart from the missing buildings - new construction, literal reconstruction and reconstruction of the exterior image - "change of skin" - looking at Table 1, it is clear that those buildings closest to the front, and hence more damaged, provoked a greater variety of solutions. Nevertheless, in the case of those which suffered less damage the most conservative option was chosen: literal reconstruction.

In addition, as a methodological conclusion, we must point out that graphic production becomes an inherent part of this work and - in its way - is itself also a conclusion. It is via this means that all the gathered information is brought together and analysed, obtaining images that bring us closer to a lost past of our Heritage.

Finally, it can be said that - like any other city - the CU we know today is the result of the overlap of layers that History has been depositing one on top of another. However, the interest in this palimpsest of political ideas, architectural styles and social hopes is rather unique, since it condenses within it - in a rather intense way - the history of Spain's 20th century.

\section{ACKNOWLEDGEMENT}

Jara Muñoz Hernández has a pre-PhD contract (FPU) financed by the Ministry of Education, Culture and Sports (FPU15/01782).

\section{REFERENCES}

[1] Momoitio, I. \& Núñez Monasterio, A. (eds), Falling and Raising. Heritage Reconstruction After a War, Fundación Museo de la Paz de Gernika: Gernika, 2016.

[2] Ortega Vidal, J., Martínez Díaz, Á. \& Muñoz de Pablo, M.J., Drawing and building life. EGA. Journal of Architectural Graphic Expression, 18, pp. 50-63, 2011.

[3] González Casas, J.L. \& Muñoz Hernández, J., Drawing for heritage dissemination. The birth of Madrid's Ciudad Universitaria. International Journal of Heritage Architecture, 2(2), pp. 359-371, 2018.

[4] Fernández Talaya, M.T., La Florida and La Moncloa Royal Estate: Historical and Artistic Developement of a Madrid Site, Fundación Cajamadrid: Madrid, 1999.

[5] Rodríguez-López, C. \& Muñoz Hernández, J. (eds), Towards the Centenary. 90 Years of Madrid's Ciudad Universitaria, Ediciones Complutense: Madrid, 2018.

[6] Chías Navarro, P., Madrid's Ciudad Universitaria, Universidad Complutense de Madrid: Madrid, 1986.

[7] Calvo González-Regueral, F., The Civil War in the Ciudad Universitaria, La Librería: Madrid, 2012.

[8] González Ruibal, A. et al., War in the university: Archeology of the conflict in Madrid's Ciudad Universitaria. Ebre, 38(4), pp. 123-143, 2010.

[9] González Cárceles, J.A., Ciudad Universitaria's war front. The Faculty of Philosophy and Letters of Madrid in the Second Republic, eds S. López-Ríos \& J.A. González Cárceles, Madrid's Town Council: Madrid, pp. 552-573, 2008.

[10] Rodríguez López, C., Landscapes of a War: Madrid's Ciudad Universitaria, Universidad Complutense de Madrid: Madrid, 2015.

[11] Crowley, D., Warsaw, Reaktion Books: London, 2003.

[12] Rodríguez-López, C., The University of Madrid During the First Francoism (19391951): Rupture and Continuity, Dykinson: Madrid, 2002. 